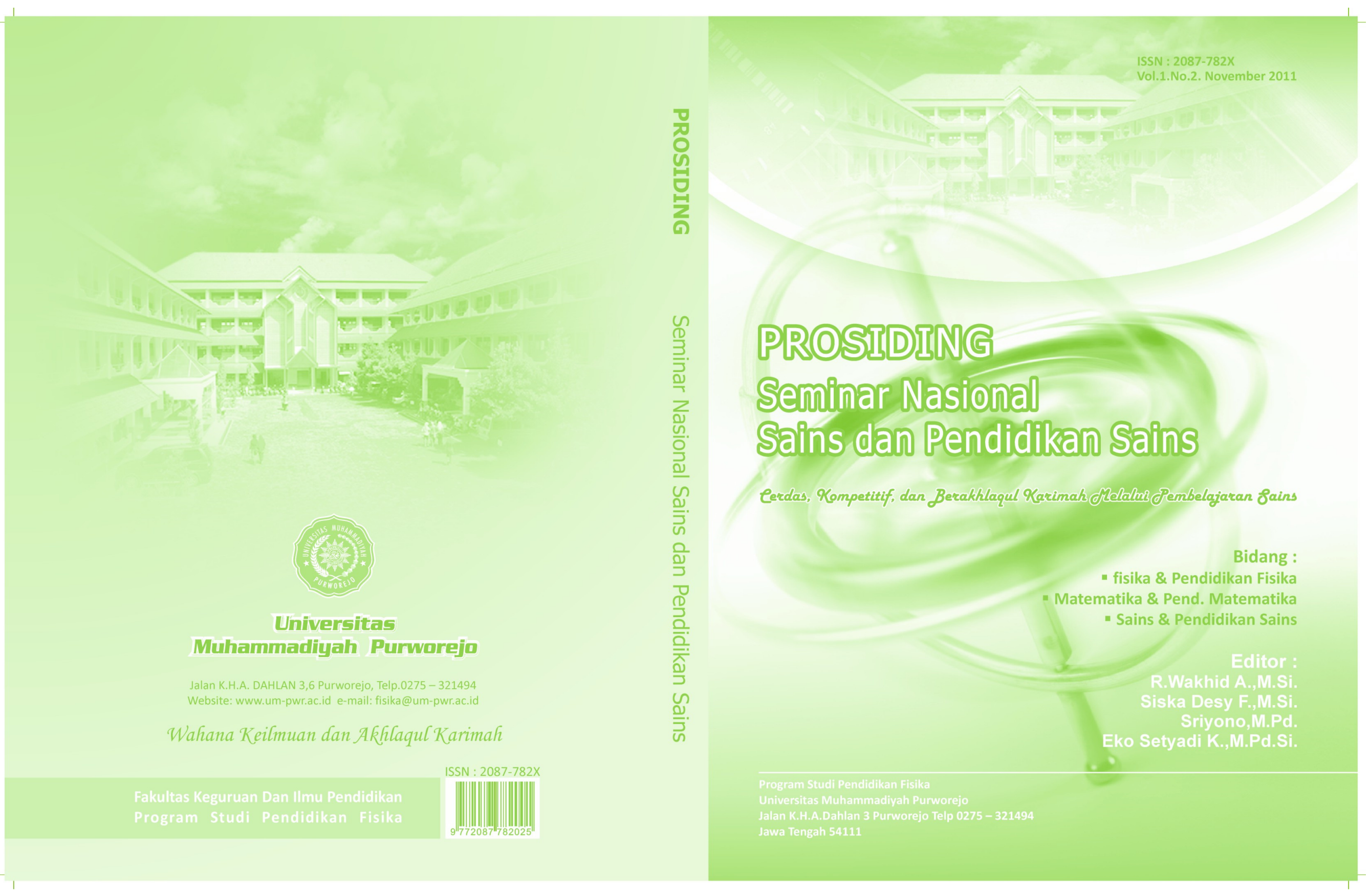




\section{PROSIDING} SEMINAR NASIONAL SAINS DAN PENDIDIKAN SAINS 2

\section{Dewan Redaksi/ Editor :}

R. Wakhid Akhdinirwanto, M.Si.

Siska Desy Fatmaryanti, M.Si.

Sriyono, M.Pd.

Eko Setyadi Kurniawan, M.Pd.Si.

Alamat Redaksi

Program Studi Pendidikan Fisika

Fakultas Keguruan dan Ilmu Pendidikan

Universitas Muhammadiyah Purworejo

Jalan KH.A.Dahlan 3 Purworejo, Jawa Tengah 54111, Telp. 0275 - 321494,

e-mail : ekosetyadik@gmail.com 


\section{KATA PENGANTAR}

\section{Bismillahirohmanirokhim}

\section{Assalamu'alaikum Wr.Wb.}

Puji syukur marilah kita panjatkan ke haribaan Allah SWT karena atas rahmat dan nikmatNya, sehingga "SEMINAR NASIONAL SAINS DAN PENDIDIKAN SAINS 2" dengan tema: Cerdas, Kompetitif dan Berakhlaqul Karimah melalui Pembelajaran Sains telah dapat kami selenggarakan. Kegiatan ini merupakan kegiatan tahunan yang sudah berjalan untuk yang kedua kali, yang diselenggarakan oleh Program Studi Pendidikan Fisika Universitas Muhammadiyah Purworejo. Dalam kegiatan Seminar hari ini telah dipresentasikan 2 makalah utama yang disampaikan oleh Dr. Khairil Anwar dan Dr. Ariswan, kemudian dilanjutkan presentasi oral dalam sesi paralel yang berjumlah 66 makalah dari berbagai institusi dari berbagai wilayah di Indonesia. Makalah dibagi dalam 4 bidang yaitu Bidang Fisika 19 makalah, Bidang Pendidikan Fisika 28 makalah, Bidang Matematika dan Pendidikan Matematika sejumlah 9 makalah, dan Bidang Sains dan Pendidikan Sains 10 makalah.

Akhirnya, kami selaku penitia penyelenggara mohon maaf yang sebesar-besarnya, apabila ada hal-hal yang kurang berkenan selama dan sesudah penyelenggaraan kegiatan Seminar Nasional ini. Semoga Seminar Nasional ini dapat memberi manfaat bagi kita semua, khususnya kemajuan ilmu pengetahuan dan teknologi di Indonesia. Akhirnya, kami ucapkan sampai berjumpa kembali di Seminar Nasional HFI 2012 dan Seminar Nasional Sains dan Pendidikan Sains 3 di tahun 2013.

\section{Wassalamu'alaikum Wr.Wb}

Purworejo, November 2011

Ketua Panitia

Drs. R.Wakhid Akhdinirwanto, M.Si. 


\section{DAFTAR ISI}

Editor

Kata Pengantar

Daftar Isi

Makalah Utama

PEMBELAJARAN SAINS MENCERDASKAN DAN MEMANTAPKAN KARAKTER BANGSA

Ariswan

\section{Bidang Fisika}

1. ANALISIS GEMPA VULKANIK PADA LETUSAN GUNUNG MERAPI 2010 DARI DATA SEISMIK BROADBAND DI STASIUN WANAGAMA YOGYAKARTA DENGAN DEKOMPOSISI WAVELET

Dairoh, Wiwit Suryanto.

2. PEMETAAN SEBARAN POLUTAN KIMIA LEACHATE DENGAN METODE GEOLISTRIK KONFIGURASI SCHLUMBERGER DI SEKITAR TEMPAT PEMBUANGAN AKHIR SAMPAH BANYU URIP MAGELANG

Suharjo, Thaqibul Fikri Niyartama.

3. ALAT SEDERHANA UNTUK MENENTUKAN INDEKS BIAS CAIRAN NON HOMOGEN DENGAN METODE BELOKAN SINAR LASER

Meinani Dwi Setyowati

4. ANALISIS KUALITAS RANGKAIAN PENYEARAH GELOMBANG PENUH MELALUI KRITERIA NILAI SIMPANGAN BAKU

Haris Rosdiyanto, Moh.Toifur

5. IDENTIFIKASI KEBERADAAN URAT SULFIDA BERASOSIASI EMAS DENGAN METODE GEOLISTRIK RESISTIVITAS KONFIGURASI WENNER SOUNDING DI DAERAH SANGON II, KOKAP, KULON PROGO, YOGYAKARTA

Supriyatno, Thaqibul Fikri Niyartama...

6. Model Arus Tegangan Sel Surya Organik Polimer P3HT : PCBM

Yusro Al Hakim, Siska Desy F , Kuwat Triyana, Chotimah

7. MENGANALISIS KONSEP GOTONG ROYONG DENGAN KONSEP INTERFERENSI GELOMBANG

Arif Purnama, W.S.B. Dwandaru

8. PEMBUATAN DAN PENGUJIAN SENSOR GETARAN ELEKTROLIT

Badaruddin, Wiwit Suryanto dan Suparwoto

9. PENENTUAN JARAK PISAH DUA KUMPARAN YANG MENGHASILKAN FREKUENSI TOLAKAN

M. Firman Ramadhan, Moh.Toifur.

10. PEMODELAN GROUND-PENETRATING RADAR DENGAN METODE BEDA HINGGA RANAH WAKTU UNTUK KASUS PIPA TERPENDAM JENIS LOGAM YANG TERALIRI AIR

Afif Rakhman

11. PENGARUH LUAS PERMUKAAN ELEKTRODA TERHADAP BESARNYA TEGANGAN LISTRIK PADA ELEMEN VOLTA DARI BLIMBING WULUH SEBAGAI SUMBER ENERGI LISTRIK ALTERNATIF

Supardianningsih, Yogi Setiawan, Nur Ngazizah. 
12. PENGUKURAN RESOLUSI RUANG/SPASIAL TOMOGRAFI ULTRASONIK MELALUI PENGUKURAN FUNGSI SEBAR GARIS ATAU LINE SPREAD FUNCTION (LSF)

Ego Srivajawaty Sinaga ${ }^{1)}$ Kusminarto.

13. PENGARUH SUARA "ORONG-ORONG" TERMANIPULASI PADA PEAK FREQUENCY $(5,2 \pm 0,3) 10^{3} \mathrm{~Hz}$ TERHADAP PERTUMBUHAN DAN PRODUKTIVITAS TANAMAN KEDELAI (Glycine max (L.) Merril)

Hendri Nugrahaningrum, Agus Purwanto, Nur Kadarisman

14. MENENTUKAN KONSTANTA PEGAS MENGGUNAKAN PEGAS TEKAN DAN TARIK DENGAN DIAMETER YANG DIVARIASIKAN SERTA MENENTUKAN HUBUNGAN ANTARA KONSTANTA PEGAS DENGAN DIAMETERNYA

Aan Sugiyanto, Dedi Efendi, Ali Umar Dani.

16. ESTIMASI KEDALAMAN KERAK BUMI DI JAWA TENGAH BERDASARKAN WAKTU TIBA GELOMBANG SEISMIK

Titan Parasita Siradj dan Wiwit Suryanto

17. STUDI PENGARUH GAYA PASANG SURUT SEBAGAI PEMICU GEMPA BUMI: STUDI KASUS GEMPA BUMI M $\geq 6$,4 DI INDONESIA ANTARA TAHUN 2001-2011

Kristian Purwo Nugroho, Wiwit Suryanto.

18. PENGARUH PEMAPARAN BUNYI JANGKRIK TERMANIPULASI PADA PEAK FREQUENCY $(5,26 \pm 0,03) 10^{3} \mathrm{~Hz}$ TERHADAP PERTUMBUHAN DAN PRODUKTIVITAS TANAMAN BAWANG MERAH (Allium ascalonium L)

Harlina Ardiyantio.

19. PENGARUH PERLAKUAN SUARA BELALANG "KECEK" YANG DIMANIPULASI PADA PEAK FREQUENCY $(4,50 \pm 0,02) 10^{3}$ HZ TERHADAP PERTUMBUHAN DAN PRODUKTIVITAS TANAMAN KACANG TANAH

Esti Setyaningrum, Nur Kadarisman, Agus Purwanto.

20. REKAYASA TEKNOLOGI GASING (SAWANGAN) TRADISIONAL SEBAGAI INPUT DEVICE AUDIO GROWTH SYSTEM HEMAT ENERGI DALAM PEMUPUKAN DAUN (FOLIAR) UNTUK PENINGKATAN PRODUKTIVITAS TANAMAN PERTANIAN DI DAERAH BERANGIN KENCANG

Nur Kadarisman, Agus Purwanto, Juli Astono, Joko Sudomo, Pujianto.

\section{Bidang Pendidikan Fisika}

18. PENINGKATAN KETRAMPILAN PROSES MELALUI PEMANFAATAN MEDIA

REALITA IPA PADA SISWA SMP NEGERI 1 PREMBUN

Nur Prasetiyo, R. Wakhid Akhdinirwanto, Siska Desy F.

19. STRATEGI PENINGKATAN KUALITAS DAN RELEVANSI MATERI AJAR DENGAN TEKNOLOGI TEPAT GUNA MELALUI PENGEMBANGAN SENSOR BERBASIS DEFLEKSI LASER PADA MATA KULIAH FISIKA LASER

Nur Kadarisman

20. PEMANFAATAN MODEL PEMBELAJARAN PROBLEM SOLVING UNTUK PENINGKATAN AKTIVITAS BELAJAR PADA SISWA SMP MUHAMMADIYAH SIDAREJA

Setya Astuti Wijayanti, R. Wakhid Akhdinirwanto.

21. PENINGKATAN HASIL BELAJAR SISWA KELAS VIII DENGAN MODEL COOPERATIVE LEARNING TIPE FORMULATE SHARE LISTEN CREATE (FSLC) PADA PEMBELAJARAN FISIKA

Siti Fatimah, Thaqibul Fikri Niyartama, Ika Kartika 
22. PEMANFAAATAN MODEL PEMBELAJARAN PROBLEM SOLVING UNTUK PENINGKATAN KETERAMPILAN BERPIKIR KRITIS SISWA DI KELAS VIII A SMP N 7 KEBUMEN

Evi Nurulwati, R. Wakhid Akhdinirwanto

23. MELALUI DEMONSTRASI MEMBUAT SAMBAL DENGAN ALAT DAPUR (COBEK DAN MUNTHU) DAPAT MENINGKATKAN PEMAHAMAN

GAYA GESEK

R. Hady Wahono

24. PEMANFAATAN PERAGA SEDERHANA GUNA MENJELASKAN PROSES TERJADINYA HUJAN, SIANG MALAM, DAN GUNUNG MELETUS PADA ANAK USIA DINI

Siti Ngatiqoh, Purmiati, Eko Setyadi K.

25. PENERAPAN PROJECT BASED LEARNING DENGAN PENDEKATAN KOLABORATIF PADA MATAKULIAH GRAVITASI DAN GEOMAGNET UNTUK MENINGKATKAN PEMAHAMAN KONSEP DAN KEMAMPUAN DATA PROCESSING MAHASISWA

Sehah, Hartono

26. PEMANFAATAN MEDIA VOICE THERMOMETER UNTUK MENINGKATKAN HASIL BELAJAR SISWA TUNANETRA PADA PEMBELAJARAN FISIKA POKOK BAHASAN SUHU DAN KALOR

Prisilia Ayu Arimbi, Yuli Astono, Pujianto

27. PENINGKATAN MOTIVASI BELAJAR MELALUI SENAM OTAK PADA SISWA SMP NEGERI 5 WATES

R. Wakhid Akhdinirwanto.

28. PENINGKATAN KEMANDIRIAN BELAJAR SISWA DENGAN PENGGUNAAN MEDIA ANIMASI PADA SISWA KELAS VIII MTs NEGERI II KEBUMEN

Adi Wibowo,Siska Desy Fatmaryanti, Arif Maftukhin

29. PENDEKATAN PEMBELAJARAN FISIKA BERBASIS MASALAH DENGAN PENEKANAN REPRESENTASI UNTUK MENINGKATKAN KETERAMPILAN BERPIKIR KREATIF

Arjena Faizal Nurachdila, Mundilarto, Rahayu D.S.R

30. PENERAPAN PEMBELAJARAN INKUIRI BERMEDIA PENGGARIS TERMODIFIKASI UNTUK MENINGKATKAN HASIL BELAJAR PADA KOMPETENSI SUHU SKALA TERMOMETER DAN PENGUKURANNYA BAGI SISWA KELAS VII SMP NEGERI 18 PURWOREJO

Budi Arwanto

31. UPAYA PEMBELAJARAN FISIKA UNTUK MENINGKATAN HASIL BELAJAR SISWA DALAM UJIAN NASIONAL PADA KELAS XII IPA SMA NEGERI 1 GOMBONG TAHUN 2008 DAN 2009

M. Yasin Kholifudin

31. PENINGKATAN INTERPERSONAL SKILL MELALUI PEMBELAJARAN KOOPERATIF TIPE STAD (STUDENT TEAMS-ACHIEVEMENT DEVISIONS) PADA SISWA MTS ALGHAZALI MIRIT KEBUMEN

Hidayatul Mukarromah, R. Wakhid Akhdinirwanto, Arif Maftukhin

31. ALAT PERCOBAAN FISIKA DARI BAHAN SEDERHANA UNTUK MENINGKATKAN PEMAHAMAN KONSEP FISIKA DI SMA SEBAGAI PERWUJUDAN PENDIDIKAN KARAKTER

Heru Wahyudi 
31. PENERAPAN METODE NUMBERED HEAD TOGETHER (NHT) UNTUK PENINGKATAN PARTISIPASI SISWA MTS NEGERI 1 TRIWARNO KUTOWINANGUN Rif'an Faidah, R. Wakhid Akhdinirwanto

31. PENGARUH LATAR BELAKANG PENDIDIKAN ORANG TUA DAN MOTIVASI BERPRESTASI TERHADAP PRESTASI BELAJAR FISIKA KELAS X SMA NEGERI SEKABUPATEN KEBUMEN TAHUN PELAJARAN 2008/ 2009

Sriyono, Sri Wahyuningsih.

31. PENINGKATAN MINAT DAN AKTIVITAS BELAJAR FISIKA SISWA MELALUI PENDEKATAN LEARNING COMMUNITY DENGAN METODE DEMONSTRASI

R. Hady Wahono

\section{Bidang Matematika dan Pendidikan Matematika}

32. MENGUJI VALIDITAS DAN RELIABILITAS SOAL ULANGAN AKHIR SEMESTER 1 PELAJARAN MATEMATIKA TAHUN PELAJARAN 2010/2011 BUATAN GURU SEKOLAH DASAR NEGERI DI KECAMATAN NGOMBOL

Abu Syafik, Budiyono, Nandya Masita

33. PERAMALAN CURAH HUJAN BULANAN KABUPATEN CILACAP DENGAN METODE ARIMA MUSIMAN

Agustini Tripena.

34. ANALISIS KESALAHAN MAHASISWA PENDIDIKAN MATEMATIKA DALAM MEMAHAMI KONSEP-KONSEP MATEMATIKA SEKOLAH MENENGAH ATAS

Budiyono Uswatun Khasanah

35. EKSPERIMEN MODEL PEMBELAJARAN KOOPERATIF TIPE STAD DAN JIGSAW II PADA MATERI BANGUN RUANG SE-GUGUS GATUTKACA KEC. BAGELEN KAB. PURWOREJO TAHUN PELAJARAN 2010/2011

Budiyono, Hariyati Listyaningrum.

36. PEMBELAJARAN DIMENSI TIGA BERCIRIKAN PEMBERDAYAAN KEGIATAN BELAJAR KELOMPOK BERPOTENSI MENUMBUHKAN KECERDASAN INTELEKTUAL, KECERDASAN EMOSIONAL, DAN KECERDASAN SPIRITUAL SECARA SINERGI

Suhito

\section{Bidang Sains dan Pendidikan Sains}

41. PENGGUNAAN MODUL BERBASIS DOMAIN SIKAP SAINS UNTUK PENANAMAN KARAKTER PADA SISWA SMP NEGERI 7 KEBUMEN

Rini Ariyanti, R. Wakhid Akhdinirwanto, Siska Desy Fatmaryanti.

43. PEMANFAATAN LEMPUNG SINTETIS HYRDROTALCITE BAGI PEMISAHAN FRAKSI ASAM HUMAT DARI PERAIRA

Karmanto

44. MEMBANGUN KARAKTER PESERTA DIDIK MELALUI PEMBELAJARAN SAINS BERBASIS PENDIDIKAN NILAI (LIVING VALUES ACTIVITIES)

Dian Noviar

45. PEMANFAATAN ZnO/ZAH UNTUK MENDEGRADASI RODHAMIN B DAN METHYL RED

Dwi Kartika, Puji Lestari. 


\title{
ANALISIS KUALITAS RANGKAIAN PENYEARAH GELOMBANG PENUH MELALUI KRITERIA NILAI SIMPANGAN BAKU
}

\author{
Haris Rosdianto, Moh. Toifur \\ Program Magister Pendidikan Fisika, Universitas Ahmad Dahlan, Yogyakarta \\ Kampus II, Jl.Pramuka 42, Yogyakarta 55161 \\ Telp.081522622935 email: harisrosdianto@yahoo.com
}

\begin{abstract}
ABSTRAK
Untuk menghasilkan arus searah dari input gelombang sinusoidal (arus bolak-balik) dapat digunakan sebuah proses yang disebut penyearah gelombang penuh. Komponen elektronik yang berperan di sini adalah dioda, salah satunya dioda zenner. Dioda zenner memiliki banyak tipe dengan konfigurasinya masing-masing. Dioda seperti apakah yang paling baik digunakan dalam rangkaian penyearah gelombang penuh? Untuk membuat sebuah rangkaian penyearah gelombang penuh yang baik kita harus menggunakan jenis dioda yang tepat, dengan menggunakan empat dioda yang dirangkai menjadi penyearah jembatan (rectifier bridge). Bentuk gelombang output yang semakin lurus (simpangan bakunya semakin kecil) menunjukkan semakin baiknya kualitas rangkaian penyearah gelombang penuh.
\end{abstract}

Kata kunci: penyearah jembatan, simpangan baku

\section{PENDAHULUAN}

Statistik sangat berperan dalam kehidupan manusia. Statistik banyak digunakan untuk menganalisis data-data yang pada akhirnya akan sangat bermanfaat bagi kehidupan manusia, tak terkecuali dalam fisika. Banyak percobaan dan penelitian di bidang fisika yang dilakukan oleh banyak fisikawan memanfaatkan statistik. Seperti halnya penelitian yang dilakukan peneliti dalam makalah ini. Di sini peneliti mencoba menganalisis kualitas dari rangkaian penyearah gelombang penuh melalui kriteria nilai simpangan bakunya. Di mana semakin kecil nilai simpangan bakunya, maka sebaran datanya akan semakan seragam ${ }^{[4]}$. Dalam hal ini berarti semakin kecil nilai simpangan bakunya, maka kualitas rangkaian penyearah gelombang penuh tersebut semakin baik.

Sementara percobaan tentang penyearah arus sendiri sudah banyak dilakukan oleh siswa-siswa di sekolah dan mahasiswa di perguruan tinggi. Tapi hanya terbatas dalam mempelajari prinsip kerka karakteristik dari penyearah arus itu sendiri, Penulis dalam hal ini menitikberatkan pada jenis dioda yang digunakan, karena penulis ingin meneliti kriteris dioda seperti apa yang paling digunakan sebagai penyearah arus. Penyearah gelombang penuh sistem jembatan dipilih karena dapat memperlihatkan data-data yang menunjukkan criteria dioda tanpa adanya pengaruh dari faktor lain (penyearah gelombang penuh dengan menggunakan trafo CT, dikhawatirkan ada pengaruh dari faktor trafo). Dalam pengambilan data, penulis memanfaatkan perangkat Logger Pro dan dalam pengolahan datanya penulis memanfaatkan program MS Excel dan Igor Pro

\section{LANDASAN TEORI}

\section{PENYEARAH (RECTIFIER)}

Tegangan arus searah biasanya dibutuhkan untuk mengoperasikan peralatan elektronik, misalnya pesawat amplifier, peralatan kontrol elektronik, peralatan komunikasi dan sebagainya. Catu daya arus searah (DC) dapat dipeloreh dari batere atau dari sumber daya listrik 220/240 Volt Ac $50 \mathrm{~Hz}$ yang dirubah menjadi arus searah melalui rangkaian penyearah (rectifier $)^{[3]}$.

Umumnya penyearah arus terdiri dari dua jenis, penyearah setengah gelombang dan penyearah gelombang penuh. Rangkaian penyearah gelombang penuh dapat diperoleh dengan dua cara. Cara 
pertama memerlukan transformator sadapan pusat (Centre Tap-CT). Cara yang lainnya adalah dengan menggunakan empat dioda disebut penyearah jembatan (rectifier bridge ${ }^{[1][2][3]}$. Dalam makalah ini penulis hanya akan meneliti tentang penyearah gelombang penuh dengan penyearah jembatan

Rangkaian penyearah ini memerlukan empat buah dioda yang dipasang dengan konfigurasi jembatan seperti terlihat pada gambar 1 .
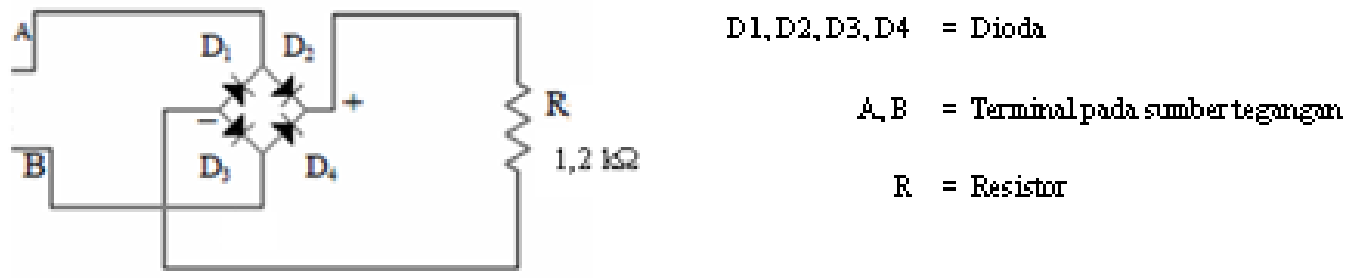

Gambar 1. Rangkaian Penyearah Sistem Jembatan

Pada saat terminal A positif dan B negatif, dioda-dioda D2 dan D3 berada dalam kondisi menghantar sedangkan D4 dan D1 tidak menghantar. Pada saat terminal A negatif dan B positip, dioda yang menghantar adalah D4 dan D1, sedang D2 dan D3 tidak menghantar. Dengan demikian setiap setengah perioda tegangan bolak balik ada dua dioda yang menghantar (conduct) secara bersamaan dan dua buah dioda lainnya tidak menghantar sehingga menghasilkan bentuk gelombang penuh. Bentuk gelombang keluaran terlihat seperti gambar 2.

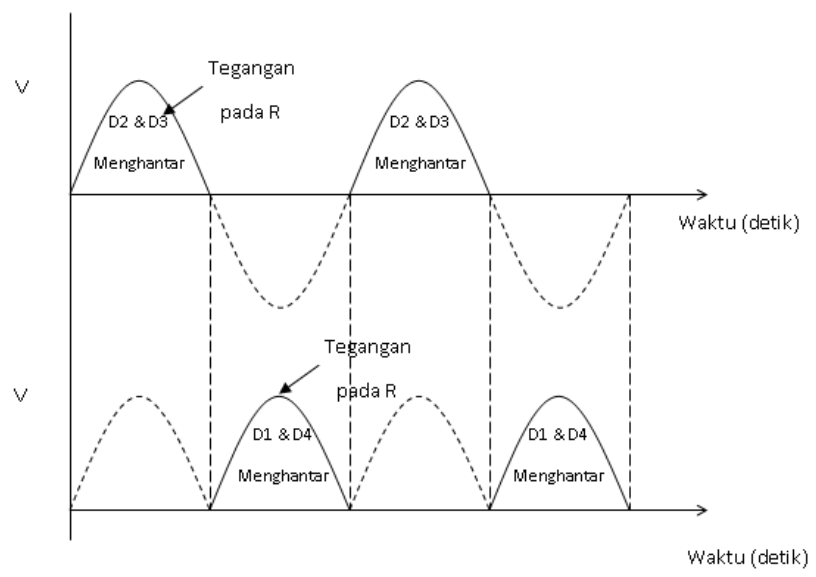

Gambar 2. Bentuk Gelombang Tegangan Output

\section{PENGERTIAN STANDAR DEVIASI}

Standar deviasi digunakan untuk menjelaskan homogenitas kelompok ${ }^{[4]}$. Varians merupakan jumlah kuadrat semua deviasi nilai-nilai individual terhadap rata-rata kelompok. Sedangkan akar dari varians disebut dengan standar deviasi atau simpangan baku.

Simpangan baku merupakan variasi sebaran data. Semakin kecil nilai sebarannya berarti variasi nilai data makin seragam. Jika sebarannya bernilai 0 , maka nilai semua datanya adalah sama. Semakin besar nilai sebarannya berarti data semakin bervariasi ${ }^{[4]}$.

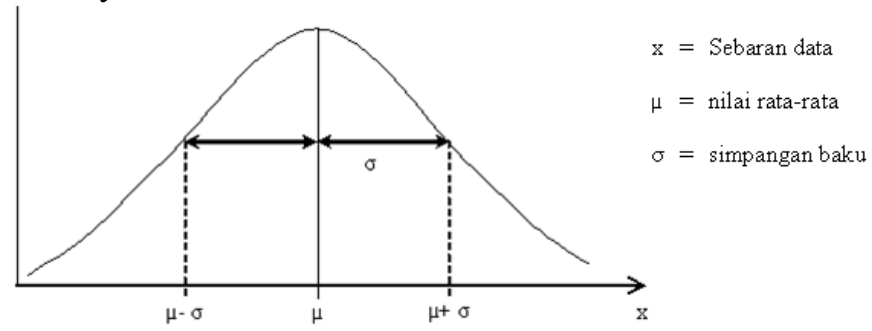

Gambar 3. Contoh grafik distrubusi normal Gaussian 
Jadi dalam percobaan yang dilakukan oleh peneliti, semakin kecil nilai simpangan bakunya berarti variasi nilai tegangan output semakin sama dan gelombang output yang dihasilkan akan semakin lurus.

Dari tiap-tiap tipe dioda zenner yang digunakan akan dicari simpangan bakunya untuk menentukan kualitas dari rangkaian penyearah arus. Semua perhitungan dilakukan dengan memanfaatkan fungsi-fungsi persamaan yang ada pada program Microsoft Excel, yang nantinya akan dibandingkan dengan hasil perhitungan dengan menggunakan perangkat Igor Pro 4.03. Lalu dari tiaptiap tipe dioda ditentukan distribusi normal Gaussian-nya.

Persamaan-persamaan yang digunakan adalah sebagai berikut:

$\mu=\frac{1}{\mathrm{~N}} \sum_{i}^{n} x_{i}$

$$
\sigma=\sqrt{\frac{1}{\mathrm{~N}} \sum_{i}^{n}\left(x_{i}-\mu\right)^{2}}
$$

$$
\operatorname{Pg}_{\mathrm{i}}(\mathrm{x} ; \mu, \sigma)=\frac{1}{\sigma \sqrt{2 \pi}} \exp \left[-\frac{1}{2}\left(\frac{\mathrm{x}_{\mathrm{i}}-\mu}{\sigma}\right)^{2}\right]
$$

$$
\text { Keterangan : } \begin{aligned}
& \mathrm{x}_{\mathrm{i}}=\text { data ke-i }(\mathrm{i}=1,2,3, \ldots \mathrm{n}) \\
& \mathrm{N}=\text { banyaknya data } \\
& \mu=\text { nilai rata-rata dari data } \\
& \sigma=\text { simpangan baku } \\
& \mathrm{Pg}_{\mathrm{i}}=\text { distribusi normal Gaussian }
\end{aligned}
$$

Kemudian dibuat grafik distribusi normal Gaussian masing-masing dioda menggunakan program Igor Pro 4.03..

\section{PERANGKAT KOMPUTASI YANG DIGUNAKAN}

\section{Igor Pro 4.03}

Igor merupakan sebuah program terintegrasi untuk menampilkan, menganalisa, mengubah dan mempresentasikan data.

Fitur-fitur yang terdapat dalam program Igor antara lain :

1. Tampilan grafik yang berkualitas baik

2. Tampilan data berkecepatan tinggi

3. Kemampuan untuk mengolah data dalam jumlah besar

4. Fitting gelombang, transformasi fourier, memperhalus tampilan grafik, histogram dan metode analisis yang lain

\section{Logger Pro 3.2}

Perangkat Logger Pro merupakan salah satu cara yang murah dan mudah digunakan oleh para siswa untuk mengumpulkan dan menganalisa data menggunakan komputer. Program ini bekerja dilkombinasikan dengan interface yang menghubungkan perangkat percobaan dengan komputer. Dengan menggunakan interface ini, para siswa dapat dengan mudah mengukur besaran fisika seperti temperatur, $\mathrm{pH}$, tekanan, intensitas cahaya, dan lain-lain. Perangkat keras dan lunak mempermudah proses pengambilan data dan mempersingkat waktu dalam pengumpulan data dalam jumlah besar. Dalam penggunaannya tidak perlu dilakukan penyetingan lagi karena hanya berfungsi sebagai interface saja, sehingga data yang diperoleh merupakan data yang memang dari eksperimen. 


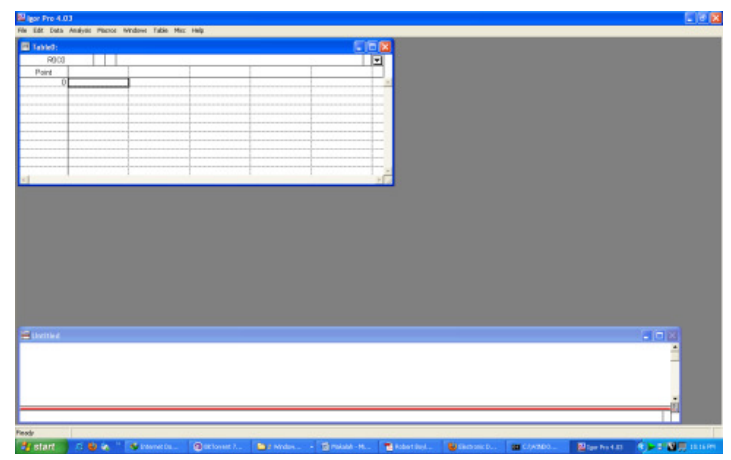

(a)

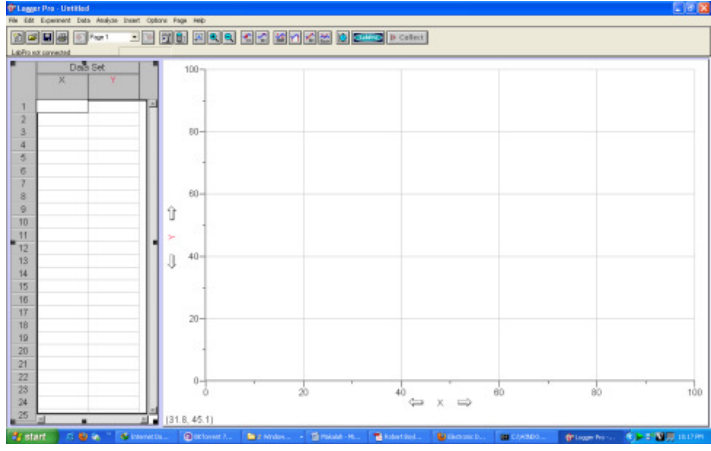

(b)

Gambar 4. (a) Tampilan program Igor Pro 4.03, dan (b) tampilan program logger Pro 3.2

\section{ALAT DAN BAHAN}

1. Sumber tegangan AC

2. Resistor

3. 6 jenis Dioda Zenner, yaitu : 1N4728 3.3V, 1N4730 3.9V, 1N4732 4.7V, 1N4734 5.6V, 1N4736

$6.8 \mathrm{~V}, 1 \mathrm{~N} 47388.2 \mathrm{~V}$ masing-masing 4 buah

4. Kabel penghubung secukupnya

5. Perangkat keras dan lunak Logger Pro 3.2 sebagai perekam data

6. Perangkat lunak Igor Pro 4.03 sebagai pengolah data

7. Laptop atau komputer sebagai penampil data

\section{METODE PENELITIAN}

Penelitian berbentuk eksperimen dengan rangkaian percobaan seperti pada gambar 5 di bawah ini. Sumber tegangan AC diatur dengan frekuensi $50 \mathrm{~Hz}$. Interface Logger Pro dihubungkan secara paralel dengan RL untuk mendapatkan data-data yang diperlukan serta menampilkan bentuk gelombang output-nya pada PC/Laptop. Data yang diambil berupa besar tegangan output yang direkam oleh perangkat Logger Pro selama 30 detik dengan interval waktu sebesar 0,1 detik. Dengan mengganti dioda dengan tipe yang berbeda, langkah-langkah percobaan di atas kembali dilakukan.

Data-data tersebut didapatkan dengan menggunakan interface Logger Pro yang diparalelkan dengan R dan langsung dihubungkan dengan laptop atau PC. Selain dari bentuk gelombang keluaran yang terlihat dari tampilan Loggerpro pada PC/Laptop, dari tiap-tiap tipe dioda zenner yang digunakan dalam penelitian akan dilakukan analisis untuk menghitung nilai tegangan keluaran rata-rata dan simpangan baku.

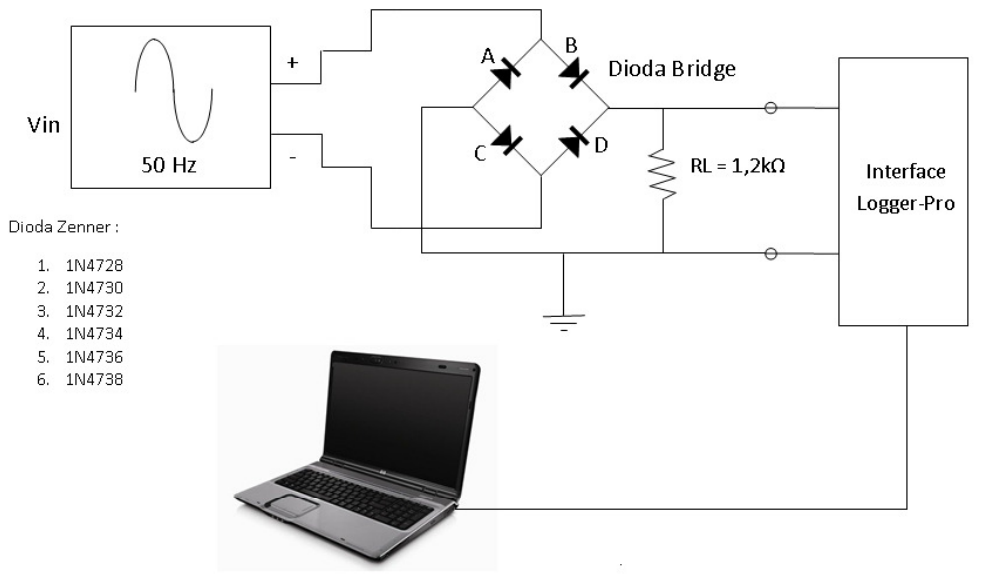

Gambar 5. Rangkaian penelitian 


\section{HASIL DAN PEMBAHASAN}

Dari percobaan yang dilakukan dengan menggunakan perangkat Logger Pro 3.2 dihasilkan bentuk gelombang output masing-masing dioda.

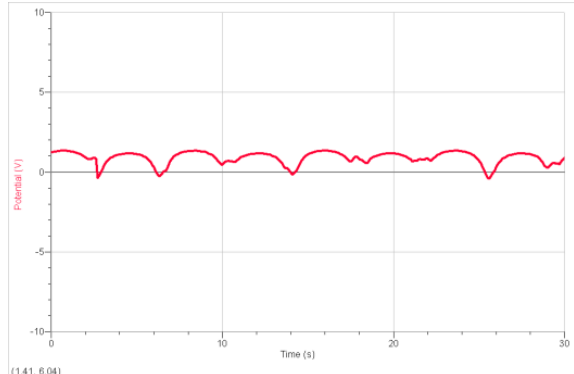

(a)

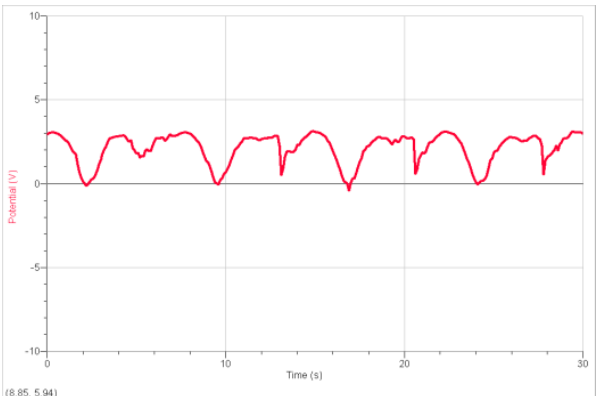

(c)

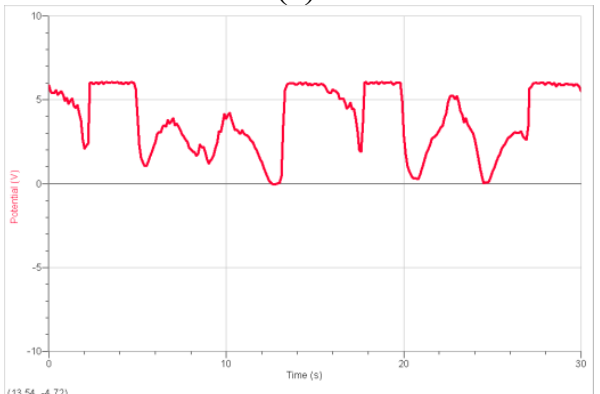

(e)

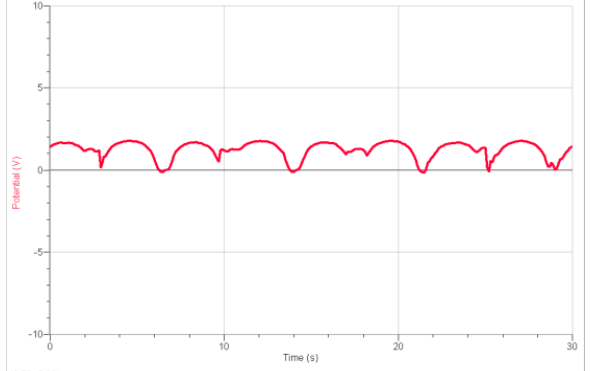

(b)

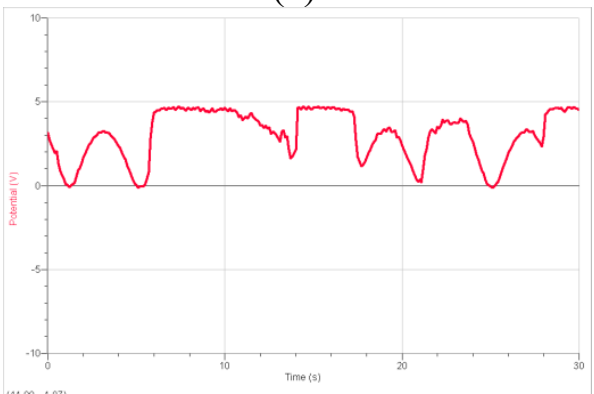

(d)

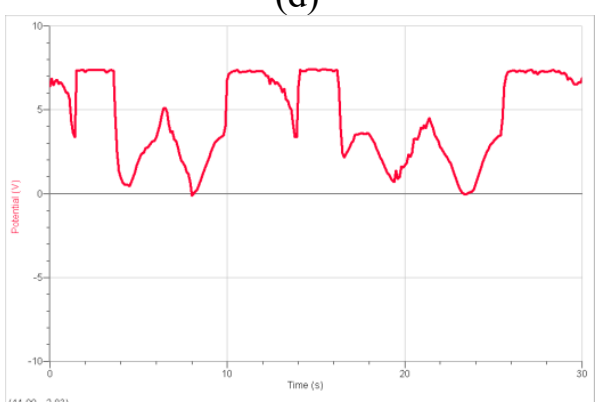

(f)

Gambar 6. Tampilan Pengukuran Rangkaian Penyearah Gelombang Penuh Menggunakan Dioda Jembatan, (a) Dioda 1N4728, (b) Dioda 1N4730, (c) Dioda 1N4732, (d) Dioda 1N4734, (e) Dioda 1N4736, (f) Dioda 1N4738

Dari data-data tersebut, masing-masing tipe dioda dicari nilai rata-rata keluarannya menggunakan rumus $\mu=\frac{1}{\mathrm{~N}} \sum_{i}^{n} x_{i}$, kemudian dari tiap-tiap jenis dioda dihitung nilai simpangan bakunya dengan menggunakan rumus $\sigma=\sqrt{\frac{1}{\mathrm{~N}} \sum_{i}^{n}\left(x_{i}-\mu\right)^{2}}$. Setelah itu dihitung probabilitas distribusi Gaussiannya masing-masing datanya menggunakan rumus $\operatorname{Pg}_{\mathrm{i}}(\mathrm{x} ; \mu, \sigma)=\frac{1}{\sigma \sqrt{2 \pi}} \exp \left[-\frac{1}{2}\left(\frac{\mathrm{x}_{\mathrm{i}}-\mu}{\sigma}\right)^{2}\right]$.

Lalu dari tiap-tiap jenis dioda, diambil data tegangan output dan distribusi Gaussian-nya, kemudian data-data tersebut disusun dari nilai terkecil ke nilai terbesar. Selanjutnya data-data tersebut dimasukkan ke dalam program igor untuk dianalisis dan dibuat grafiknya.

Di bawah ini ditampilkan tabel hasil analisis dan grafik distribusi Gaussian keenam tipe dioda yang digabung menjadi satu grafik. 
Tabel 1. Persamaan distribusi Gaussian tiap-tiap dioda menggunakan program Igor Pro 4.03

\begin{tabular}{|c|c|c|}
\hline $\begin{array}{c}\text { Tipe } \\
\text { Dioda }\end{array}$ & Persamaan Distribusi Gaussian & $\begin{array}{c}\text { Simpangan } \\
\operatorname{baku}(\sigma)\end{array}$ \\
\hline $1 \mathrm{~N} 4728$ & $P_{G}=(-3.8752 \mathrm{e}-11 \pm 8.7 \mathrm{e}-11)+(1.0241 \pm 8.61 \mathrm{e}-11) \exp \left[-\left(\frac{x-(0.89867 \pm 1.62 \mathrm{e}-11)}{(0.5509 \pm 5.31 \mathrm{e}-11)}\right)^{2}\right.$ & $0.5509 \pm 5.31 \mathrm{e}-11$ \\
\hline $1 \mathrm{~N} 4730$ & $P_{G}=(-5.1393 \mathrm{e}-11 \pm 7.89 \mathrm{e}-11)+(0.77327 \pm 7.8 \mathrm{e}-11) \exp \left[-\left(\frac{x-(1.237 \pm 2.77 \mathrm{e}-11)}{(0.72961 \pm 8.79 \mathrm{e}-11)}\right)^{2}\right]$ & $0.72961 \pm 8.79 \mathrm{e}-11$ \\
\hline $1 \mathrm{~N} 4732$ & $P_{G}=(-9.1773 \mathrm{e}-11 \pm 9.78 \mathrm{e}-11)+(0.4411 \pm 9.33 \mathrm{e}-11) \exp \left[-\left(\frac{x-(2.1232 \pm 8.68 \mathrm{e}-11)}{(1.279 \pm 3.29 \mathrm{e}-10)}\right)^{2}\right.$ & $1.279 \pm 3.29 \mathrm{e}-10$ \\
\hline $1 \mathrm{~N} 4734$ & $P_{G}=(8.7028 \mathrm{e}-12 \pm 1.27 \mathrm{e}-10)+(0.26901 \pm 1.21 \mathrm{e}-10) \exp \left[-\left(\frac{x-(3.0576 \pm 2.2 \mathrm{e}-10)}{(2.0973 \pm 9.57 \mathrm{e}-10)}\right)^{2}\right]$ & $2.0973 \pm 9.57 \mathrm{e}-10$ \\
\hline $1 \mathrm{~N} 4736$ & $P_{G}=(-1.4431 \mathrm{e}-10 \pm 1.58 \mathrm{e}-10)+(0.2051 \pm 1.46 \mathrm{e}-10) \exp \left[-\left(\frac{x-(3.9085 \pm 3.29 \mathrm{e}-10)}{(2.7508 \pm 1.94 \mathrm{e}-09)}\right)^{2}\right.$ & $2.7508 \pm 1.94 \mathrm{e}-09$ \\
\hline $1 \mathrm{~N} 4738$ & $P_{G}=(-1.1672 \mathrm{e}-11 \pm 2.31 \mathrm{e}-10)+(0.15693 \pm 2.1 \mathrm{e}-10) \exp \left[-\left(\frac{x-(4.5538 \pm 5.37 \mathrm{e}-10)}{(3.5952 \pm 4.54 \mathrm{e}-09)}\right)^{2}\right.$ & $3.5952 \pm 4.54 \mathrm{e}-09$ \\
\hline
\end{tabular}

Di bawah ini ditampilkan grafik distribusi Gaussian keenam tipe dioda yang digabung menjadi satu grafik dengan menggunakan perangkat Igor Pro 4.03

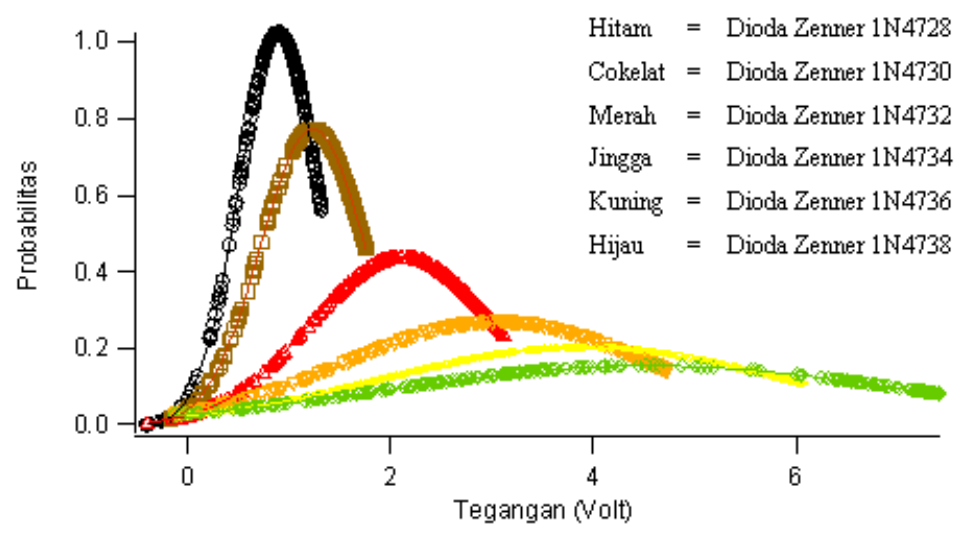

Gambar 7. Distribusi Gaussian gabungan keenam rangkaian penyearah gelombang penuh

\section{KESIMPULAN DAN SARAN}

Dari percobaan yang dilakukan peneliti dapat menarik kesimpulan :

1. Setelah mengalami penyearahan arus, bentuk gelombang output yang dihasilkan merupakan bentuk gelombang penuh. Yang membedakan gelombang output dari tiap-tiap rangkaian penyearah arus tersebut adalah tingkat kelurusan gelombang yang dipengaruhi oleh tipe dioda yang digunakan.

2. Dari bentuk gelombang dan besar simpangan baku yang dihasilkan, terlihat bahwa tipe dioda Zenner yang paling baik untuk digunakan sebagai penyearah gelombang penuh adalah tipe dioda Zenner dengan tegangan yang kecil. Dalam percobaan ini dioda Zenner 1N4728 3.3V merupakan tipe dioda yang paling baik diantara tipe-tipe dioda lain yang digunakan, karena menghasilkan nilai simpangan baku yang lebih kecil dan bentuk gelombang outputnya pun lebih lurus. 


\section{DAFTAR PUSTAKA :}

[1] D. A. Neamen, 2003, Semiconductor Physics and Devices : Basic Principles, McGraw-Hill

[2] Mohammad Ramdhani, 2008, Rangkaian Listrik, Erlangga

[3] Philip R. Bevington \& D. Keith Robinson, 2003, Data Reduction and Error Analysis for the Physical Sciences, Third Edition, McGraw-Hill Higher Education

[4] Robert Boylestad \& Louis Nashelsky, 2002, Electronic Devices and Circuit Theory 7th Edition, Prentice Hall 